\title{
ADOPSI TEORI PERILAKU BERENCANA DALAM MENGANALISIS NIAT MELAKUKAN WAKAF TUNAI
}

\author{
Fuad Hasyim ${ }^{1}$, Yulfan Arif Nurohman ${ }^{2}$ \\ IAIN Surakarta \\ 1) fuad.hasyim@iain-surakarta.ac.id \\ IAIN Surakarta \\ 2)yulfanan@gmail.com
}

\begin{abstract}
ABSTRAK
Wakaf merupakan salah satu bentuk sedekah yang dianjurkan dalam Islam. Wakaf tunai dianggap sebagai metode yang praktis karena mudah dan terjangkau untuk disumbangkan dibandingkan dengan bentuk wakaf lainnya. Penelitian ini bertujuan untuk menganalisis niat individu untuk berwakaf tunai. Adapun pendekatan yang dilakukan dengan mengadopsi teori perilaku berencana (extended theory of planned behavior/ TPB). Penelitian dilakukan dengan mengambil 96 responden yang ada di Soloraya dengan teknik clustered random sampling. Analisis data menggunakan regresi linier berganda dengan menggunakan software SmartPLS. Hasilnya menunjukkan bahwa variabel sikap, kontrol perilaku dan pengalaman berpengaruh terhadap niat sesorang dalam melakukan wakaf tunai. Sementara norma subyektif tidak berpengaruh atas niat seseorang dalam melakukan wakaf tunai.
\end{abstract}

Kata kunci: Wakaf Tunai, TPB, Extended

\section{PENDAHULUAN}

Industri keuangan syariah selalu menjadi objek kajian yang menarik, apalagi jika dibandingkan dengan kondisi industri keuangan konvensional yang sudah ada sebelumnya. Sebagai contoh, hasil penelitian Setiawan (2018) yang menyatakan bahwa perbankan syariah relatif lebih stabil dibandingkan perbankan konvensional dalam mengatasi guncangan ekonomi baik secara eksternal maupun internal. Terlebih dalam kondisi pandemi, diharapkan instrument keuangan syariah mampu membawa Indonesia keluar dari resesi dan menciptakan ketahanan ekonomi.

Salah satu instrumen penting dan memiliki potensi yang sangat besar dari segi sosial dan finansial adalah wakaf. Wakaf memiliki peran penting dalam kerangka sosial Islam (Shaikh et al. 2017). Di antara banyaknya jenis wakaf salah satunya adalah wakaf uang atau wakaf tunai. Wakaf tunai merupakan inovasi di bidang sistem keuangan sosial Islam selain zakat, infaq, dan sedekah. Wakaf tunai memiliki karakteristik yang berbeda dengan zakat, dan sedekah. Zakat, infaq, dan sedekah merupakan dana sosial yang harus disalurkan langsung kepada yang berhak; namun ada nilai pokok yang harus dipertahankan dalam penyaluran dana wakaf; selanjutnya yang harus disalurkan adalah hasil akhir atau hasil wakaf itu sendiri (Mohsin, 2013). Oleh karena itu, manfaat wakaf dapat dirasakan jika terjadi produksi yang signifikan.

Wakaf tunai dapat mengatasi masalah pembiayaan untuk pengusaha mikro jika dilakukan integrasi dengan para pengusaha mikro (Thaker et al. 2016). Selain itu, wakaf dapat menjadi alat kewirausahaan dalam mengejar kesejahteraan umat (Iman \& Mohammad, 2017). Wakaf fleksibel dalam pemanfataan dananya jika dibandingkan 
dengan zakat. Karena wakaf dapat dimanfaatkan untuk berbagai macam layanan kesejateraan umum bukan pada kalangan tertentu saja (Shaikh et al. 2017).

Di Indonesia, wakaf tunai mulai dikembangkan pada tahun 2001 ketika para Ekonom Islam melihat jumlah aset wakaf di Indonesia belum dimanfaatkan secara optimal. Oleh karena itu, pada tahun 2002, Komisi Fatwa Majelis Ulama Indonesia (MUI) mengeluarkan fatwa tentang wakaf tunai, yang meliputi: (1) wakaf tunai/wakaf al-nuqud adalah wakaf yang dilakukan oleh seseorang, lembaga atau badan hukum dalam bentuk uang tunai, (2) surat berharga juga termasuk istilah "uang", (3) wakaf uang termasuk jawaz, (4) wakaf tunai hanya dapat disalurkan dan digunakan untuk hal-hal yang dibolehkan secara syar'i, (5) nilai pokok wakaf harus dijamin kelestariannya, tidak boleh dijual, dihibahkan dan atau diwariskan. Inovasi wakaf tunai dapat berupa pembiayaan wakaf bersama (Mohamad Suhaimi et al., 2014) untuk usaha mikro (Thaker et al., 2016), tujuan pendidikan (Harun et al., 2016) yang dikumpulkan oleh berbagai metode (Shulthoni \& Saad, 2018).

Wakaf tunai memiliki potensi sangat besar untuk memperbaiki permasalahan ekonomi di Indonesia, namun penghimpunan wakaf tunai di Indonesia sendiri masih belum dilakukan secara maksimal. Terbukti seperti yang dikatakan oleh Ventje Rahardjo Soedigno sebagai Direktur Eksekutif KNEKS melihat dari BWI bahwa potensi aset wakaf tunai di Indonesia mencapai Rp 180 triliun namun total penghimpunan dana wakaf sampai pada 2017 hanya mencapai Rp 400 miliar (KNKS, 2019). Adapun informasi penghimpunan wakaf tunai 4 tahun terakhir adalah sebagai berikut

Tabel 1 : Total Penghimpunan Wakaf Tunai

\begin{tabular}{lcc}
\hline No. & Tahun & Jumlah \\
\hline 1. & 2017 & 400 Miliar \\
2. & 2018 & 225 Miliar \\
3. & 2019 & 400 Miliar \\
4. & 2020 & 391 Miliar \\
\multicolumn{3}{l}{ 永 }
\end{tabular}

Dalam perkembangannya, wakaf tunai sebenarnya semakin mudah untuk dilakukan. Banyak nazir resmi yang sudah diresmikan Badan Wakaf Indonesia. Data jumlah nadzir di Indonesia sampai dengan bulan Oktober 2019 ada 224 nadzir (BWI, 2019). Selain itu banyak lembaga bank sebagai LKS-PWU (Lembaga Keuangan Syariah Peneriwa Wakaf Uang) yang ditunjuk oleh Kementerian Agama untuk ikut menjadi bagian penghimpunan wakaf uang. Sampai saat ini terdapat 23 bank sebagai LKS-PWU (BWI, 2021).

Perbankan syariah di Indonesia sejauh ini telah menyesuaikan diri dengan perubahan zaman termasuk pada layanan online. Salah satu cara atau layanan yang disuguhkan adalah layanan bank syariah melalui e-banking-nya. E-banking memiliki beragam cara untuk melakukan transaksi mulai dari phone banking, SMS banking, $m$ banking, internet banking, maupun ATM. Untuk m-banking sendiri sudah menghadirkan fitur untuk wakaf tunai. Fitur mobile banking terkoneksi dengan layanan zakat dan wakaf (indotelko.com, 2020). Hal tersebut tentu semakin mempermudah masyarakat untuk melakukan wakaf tunai.

Penggunaan $e$-banking di masyarakat sampai saat ini terus mengalami peningkatan. Hal ini terlihat dari jumlah transaksi online yang semakin banyak dilakukan. Salah satunya dari data BRI Syariah yang menunjukkan bahwa lebih dari $70 \%$ frekuensi transaksi nasabah BRI Syariah telah dilakukan online (BRIS, 2019). Selain itu jumlah pengguna $m$-banking Syariah Mandiri meningkat 25 persen dengan beragam keperluan 
yang dilakukan seperti top up, dompet digital, pembayaran ziswaf, dan lain sebagainya (Abdila, 2020). Fenomena tersebut dapat membuat potensi terhimpunnya wakaf tunai semakin pesat.

Beberapa pendekatan telah dilakukan untuk mengevaluasi perilaku masyarakat dalam melakukan wakaf tunai. Salah satu instrumen yang sering digunakan adalah teori perilaku berencana (theory of planned behavior/ TPB). Teori perilaku berencana merupakan perluasan dari teori perilaku beraslan (theory of reasoned action/ TRA) (Ajzen, 1985, 1991; Hill et al., 1977). Dalam TPB, niat merupakan faktor utama dan dipengaruhi oleh tiga konstruk fundamental yang mempengaruhi perilaku. Ajzen (1991) mendefinisikan niat sebagai percobaan untuk melakukan perilaku tertentu oleh seseorang. TRA terdiri dari sikap dan norma sosial sebagai faktor kunci yang mempengaruhi niat untuk melakukan perilaku tertentu (Hill et al., 1977). Sedangkan TPB terdiri dari sikap, norma subjektif dan kontrol perilaku yang dirasakan. Variabel-variabel tersebut dipengaruhi oleh tiga jenis keyakinan yang menonjol yaitu keyakinan perilaku, keyakinan normatif dan keyakinan kontrol (Ajzen, 1991).

Penelitian ini menggunakan TPB yang diperluas (extended) dengan memasukkan perilaku masa lalu (pengalaman) karena beberapa penelitian sebelumnya mengungkapkan bahwa perilaku masa lalu secara signifikan mempengaruhi niat donasi (Kashif et al., 2015; Kashif \& de Run, 2015; Knowles et al., 2012). Dan juga, ditemukan bahwa perilaku masa lalu mengarah pada niat donasi di masa depan (Paco \& Rodrigues, 2014). Selain itu Ouellette \& Wood (1998) menemukan bahwa perilaku masa lalu adalah prediktor imperatif perilaku masa depan, seringkali di luar kekuatan prediktif niat perilaku dan konstruksi mapan lainnya. Oleh karena itu, penelitian ini memasukkan perilaku masa lalu untuk meningkatkan kemampuan prediksi terhadap TPB, terlebih untuk melihat sejauh mana preferensi masyarakat dalam melakukan wakaf tunai.

\section{LANDASAN TEORI DAN PENGEMBANGAN HIPOTESIS}

\section{Landasan Teori}

\section{Wakaf Tunai}

Secara terminologi, wakaf berarti al-habsu (menahan diri). Dalam bahasa Arab, waqafayaqifu-waqfan berarti habisayahbasu-habsan. Menurut definisi syariahnya wakaf berarti menahan kekayaan dan menyumbangkannya berdasarkan kehendak Allah (Sabiq, 2000; Sadeq, 2002). Pengertian ini mendefinisikan wakaf tunai sebagai dana atau uang yang dikumpulkan oleh lembaga pengelola wakaf (nadzir) melalui penerbitan sertifikat yang dibeli oleh masyarakat. Dalam istilah lain wakaf tunai juga dapat diartikan sebagai menyumbangkan kekayaan berupa uang atau surat berharga yang dikelola oleh lembaga perbankan atau lembaga keuangan syariah yang keuntungannya akan dibagikan. Namun, modalnya tidak dapat dikurangi untuk tujuan sedekah. Sedangkan dana wakaf yang terkumpul selanjutnya dapat disalurkan dan diinvestasikan oleh nadhir ke berbagai bidang usaha yang halal dan produktif, sehingga taksi keuntungannya dapat dimanfaatkan untuk pembangunan umat dan kesejahteraan bangsa secara keseluruhan (Ahmad, n.d.; Haq, 2012; Thaker et al., 2016).

Ulama Islam memiliki persepsi yang berbeda tentang wakaf tunai (Syahroni \& Karim, 2016). Pertama, sebagian ulama meyakini bahwa wakaf tunai dilarang oleh hukum Islam; kedua, sebagian berpendapat bahwa wakaf tunai diperbolehkan selama tidak untuk perhiasan; ketiga, sebagian berpendapat bahwa wakaf tunai diperbolehkan 
untuk keseluruhan hutang dan keempat sebagian ulama termasuk malikiyah dan Muhammad Abdullah al Anshar, Ibnu Taimiyah percaya bahwa wakaf tunai mutlak diperbolehkan (Syahroni \& Karim, 2016).

Menurut Mu'alim dalam Haura et al. (2015), beberapa ulama membolehkan wakaf tunai, termasuk Imam al-Zuhri (w. $124 \mathrm{H}$ ) yang menjelaskan bahwa dinar hukumnya diperbolehkan sebagai wakaf tunai, dengan menjadikan dinar sebagai modal usaha kemudian keuntungannya disalurkan ke mauquf 'alaih. Sedangkan ulama mutaqaddimin (klasik) dari Hanafi membolehkan wakaf dinar dan dirham sebagai wakaf uang. Hal ini didasarkan pada Isthsan bi al- 'Urf dalam atsar Abdullah bin Mas'ud r.a. "Apa yang dianggap baik oleh umat Islam juga dianggap baik oleh Allah, dan apa yang dianggap buruk oleh umat Islam juga buruk di mata Allah." Beberapa ulama madzhab al-Syafi'i, Abu Tsaur meriwayatkan dari Imam al-Syafi'i, juga menyatakan tentang bolehnya wakaf dinar dan dirham (uang).

Dapat disimpulkan bahwa wakaf tunai diperbolehkan karena sifatnya yang fleksibel dan memiliki manfaat yang besar yang tidak dimiliki oleh benda lain. Bahkan wakaf tunai lebih strategis dibandingkan dengan jenis wakaf lainnya karena berfungsi sebagai alat tukar. Selain itu, modal usaha lebih dibutuhkan oleh masyarakat daripada barang tidak bergerak. Misalnya, tanah hanya dapat digunakan sebagai usulan pertanian atau disewakan; namun, uang menjadi multiguna, sehingga dapat digunakan sebagai modal produktif atau sebagai biaya konsumtif (Syahroni \& Karim, 2016).

\section{Teori Perilaku}

Teori perilaku beralasan pada tahun 1980 digunakan untuk memprediksi niat individu untuk terlibat dalam perilaku pada waktu dan tempat tertentu (Hill et al., 1977). Teori ini dimaksudkan untuk menjelaskan semua perilaku di mana orang memiliki kemampuan untuk melakukan pengendalian diri. Komponen kunci dari model ini adalah niat berperilaku; niat perilaku dipengaruhi oleh sikap tentang kemungkinan bahwa perilaku akan memiliki hasil yang diharapkan dan evaluasi subjektif dari risiko dan manfaat dari hasil itu. Sementara dalam TPB ditambahkan perilaku kontrol untuk melihat tingkat kemudahan atas perilaku yang diinginkan (Ajzen, 1985, 1991). Secara sederhana, TPB merupakan teori minat/ niat yang dipengaruhi oleh tiga faktor, yakni sikap, norma subyektif dan kontrol perilaku.

Fokus utama baik TRA maupun TPB adalah minat/niat perilaku. Ini mengacu pada faktor motivasi yang mempengaruhi perilaku tertentu, dimana semakin kuat niat untuk melakukan perilaku, semakin besar kemungkinan perilaku tersebut akan dilakukan. Sikap, mengacu pada sejauh mana seseorang memiliki evaluasi yang menguntungkan atau tidak menguntungkan dari perilaku yang dilakukan. Sederhananya, sikap merupakan sesuatu yang muncul dari dalam diri untuk melakukan perilaku tertentu atau tidak. Norma subjektif, mengacu pada keyakinan tentang apakah kebanyakan orang menyetujui atau tidak menyetujui perilaku yang dilakukan oleh individu. Hal ini berkaitan dengan keyakinan seseorang tentang apakah teman sebaya dan orang-orang penting bagi orang tersebut berpikir bahwa dia harus terlibat dalam perilaku tersebut. Kontrol perilaku yang dirasakan, mengacu pada persepsi seseorang tentang kemudahan atau kesulitan melakukan perilaku yang diinginkan. Kontrol perilaku yang dirasakan bervariasi di seluruh situasi dan tindakan, yang mengakibatkan seseorang memiliki persepsi yang berbeda-beda tentang kontrol perilaku tergantung pada situasinya. Konstruk teori ini ditambahkan kemudian, dan menciptakan pergeseran dari theory of reasoned action ke theory of planned behavior. Dalam penelitian terdahulu ditemukan bahwa konstruk TPB 
berpengaruh terhadap minat perilaku (Aziz et al., 2015; Hasyim, 2018, 2019; Pavlou \& Chai, 2002; Rouibah, 2009; Shalender \& Sharma, 2021; Simamora \& Djamaludin, 2020; Wong et al., 2018). Kemudian dalam Extended TPB, dalam penelitian Paco \& Rodrigues (2014) menemukan bahwa pengalaman masa lalu (pengalaman) juga membentuk motivasi niat.

\section{Pengembangan Hipotesis}

Tinjauan penelitian sebelumnya mengungkapkan bahwa TPB telah berhasil diterapkan di banyak bidang studi termasuk dalam pengaturan perilaku memberi (sedekah) (Linden, 2011; Sakti et al., 2016; Smith \& McSweeney, 2007). Sikap merupakan salah satu faktor yang menunjukkan bahwa hal itu memang mempengaruhi niat seseorang untuk melakukan sesuatu, dan untuk menanggapi hal tersebut, peneliti mengkaji berbagai aspek yang dapat membentuk sikap. Eagly \& Chaiken (1993) berpendapat bahwa sikap adalah kecenderungan psikologis yang ditunjukkan dalam evaluasi pada entitas tertentu dengan beberapa derajat suka atau tidak suka. Konstruk sikap dapat diuraikan untuk menawarkan pemahaman yang lebih besar dan kekuatan prediksi konstruk.

Berdasarkan berbagai studi dalam pengaturan yang berbeda dari perilaku dan niat untuk terlibat dalam perilaku tersebut, sikap menjelaskan lebih dari 50\% dari varians dalam niat (Ajzen, 1991). Semakin positif sikapnya, semakin besar niatnya. Menurut Ajzen dan Fishbein dalam Hill et al., (1977), niat berperilaku dipengaruhi secara signifikan oleh sikap. Ajzen (1991) menyimpulkan bahwa sikap terhadap suatu perilaku merupakan faktor utama yang mempengaruhi niat terlepas dari norma subjektif dan kontrol perilaku yang dirasakan. Lebih lanjut, Rouibah (2009) juga menegaskan bahwa sikap terhadap suatu perilaku merupakan faktor penyumbang utama niat berperilaku. Dalam konteks perilaku berwakaf, Shukor et al. (2017) menegaskan bahwa sikap berpengaruh signifikan terhadap niat berwakaf tunai. Meskipun beberapa peneliti percaya bahwa sikap adalah prediktor niat untuk berwakaf, ada beberapa ahli di bidang wakaf yang berpandangan bahwa sikap mungkin bukan faktor yang cukup yang dapat mempengaruhi keputusan seseorang untuk berwakaf. Osman (2014) misalnya, berpendapat bahwa sikap tidak berpengaruh terhadap niat pemberian wakaf tunai. Oleh karena itu, penelitian ini dihipotesiskan sebagai berikut:

$H_{1}$ : Sikap berpengaruh terhadap niat melakukan wakaf tunai

Norma subjektif dianggap sebagai pandangan seseorang tentang perasaan orang lain untuk melakukan atau tidak melakukan perilaku tertentu (Ajzen, 1991). Meskipun demikian, Osman et al. (2019) menegaskan bahwa tidak ada hubungan antara norma subjektif dan niat untuk berpartisipasi dalam investasi hijau. Demikian pula Huda et al. (2012) menyebutkan bahwa norma subjektif tidak mempengaruhi perilaku kepatuhan zakat.

Akan tetapi dalam konteks perilaku wakaf, Osman, (2014) menemukan bahwa norma subjektif berpengaruh signifikan terhadap niat partisipasi wakaf tunai. Dalam teori ini, keyakinan normatif telah mengarah pada pembentukan norma subjektif. Beberapa penelitian juga telah menunjukkan secara empiris bahwa norma sosial berkontribusi positif terhadap niat sumbangan uang (Kashif \& de Run, 2015; Smith \& McSweeney, 2007) Hal ini juga mempengaruhi niat untuk menyumbangkan wakaf tunai (Sakti et al., 2016). Oleh karena itu, penelitian ini dihipotesiskan sebagai berikut:

$\mathrm{H}_{2}$ : $\quad$ Norma subyektif berpengaruh terhadap niat melakukan wakaf tunai 
Kontrol perilaku yang dirasakan didefinisikan sebagai keyakinan seseorang terhadap faktor-faktor yang dapat mempengaruhi kinerjanya, secara internal atau eksternal (Ajzen, 1991). Kontrol perilaku dalam konteks kinerja, juga mempertimbangkan aspek kemudahan dalam pengunaan. Kontrol perilaku yang dirasakan dalam penelitian ini mengacu pada sejauh mana wakif akan melakukan transaksi akad wakaf tunai berdasarkan aspek fasilitas yang memungkinkan adanya unsur kemudahan yang dirasakan. Dalam perspektif wakaf, Sakti et al., (2016) menegaskan bahwa persepsi kontrol perilaku berpengaruh signifikan terhadap niat untuk berpartisipasi dalam wakaf tunai. Selain itu, Osman et al., 2019), menemukan bahwa kontrol perilaku yang dirasakan adalah prediktor kuat niat untuk berinvestasi dalam investasi hijau.

Di sisi lain, Khalifa \& Shen (2008) menemukan bahwa efek kontrol perilaku yang dirasakan tidak signifikan pada niat perilaku. Akan tetapi, beberapa penelitian telah menunjukkan secara empiris bahwa kontrol perilaku yang dirasakan secara signifikan mempengaruhi niat memberikan sedekah (Kashif \& de Run, 2015; Knowles et al., 2012; Linden, 2011; Smith \& McSweeney, 2007). Demikian pula Heikal et al. (2014) menemukan bahwa persepsi kontrol perilaku mempengaruhi niat membayar zakat komersial oleh pedagang dan niat pemberian wakaf tunai (A. F. Osman, 2014; I. Osman et al., 2019).

$H_{3}$ : Kontrol Perilaku berpengaruh terhadap niat melakukan wakaf tunai

Perilaku masa lalu (pengalaman) dapat didefinisikan sebagai suatu tindakan atau reaksi seseorang dalam menanggapi rangsangan eksternal atau internal di masa lalu (Sommer, 2011). Definisi lebih lanjut diberikan oleh (Philippsen, n.d.) yang menjelaskan bahwa perilaku masa lalu bisa merujuk kapan saja, tetapi dalam penelitian ini mengadopsi penelitian (Shukor et al., 2017) yang menetapkan tiga bulan terakhir sebagai periode waktu. Beberapa penelitian terdahulu menemukan bahwa perilaku masa lalu secara signifikan memprediksi niat untuk meakukan pemberian (sedekah) (Kashif \& de Run, 2015; Knowles et al., 2012; Linden, 2011; Smith \& McSweeney, 2007).

Selain itu, Paco \& Rodrigues, (2014) mencatat pentingnya donasi masa lalu untuk memprediksi niat donasi di masa depan. Mereka menyimpulkan bahwa sangat penting untuk memfasilitasi proses donasi untuk memuaskan donor (wakif) dan meyakinkannya untuk mengulangi perilakunya. Mungkin para donor (wakif) yang pernah memberikan sumbangan di masa lalu mungkin telah mengembangkan titik acuan internal yang kuat. Senada yang disampaikan Heikal et al. (2014) mengungkapkan bahwa perilaku masa lalu memiliki determinan terkuat dari niat membayar zakat komersial Oleh karena itu, hipotesis yang diajukan adalah:

$\mathrm{H}_{4}$ : Pengalaman berpengaruh terhadap niat melakukan wakaf tunai 


\section{MODEL PENELITIAN}

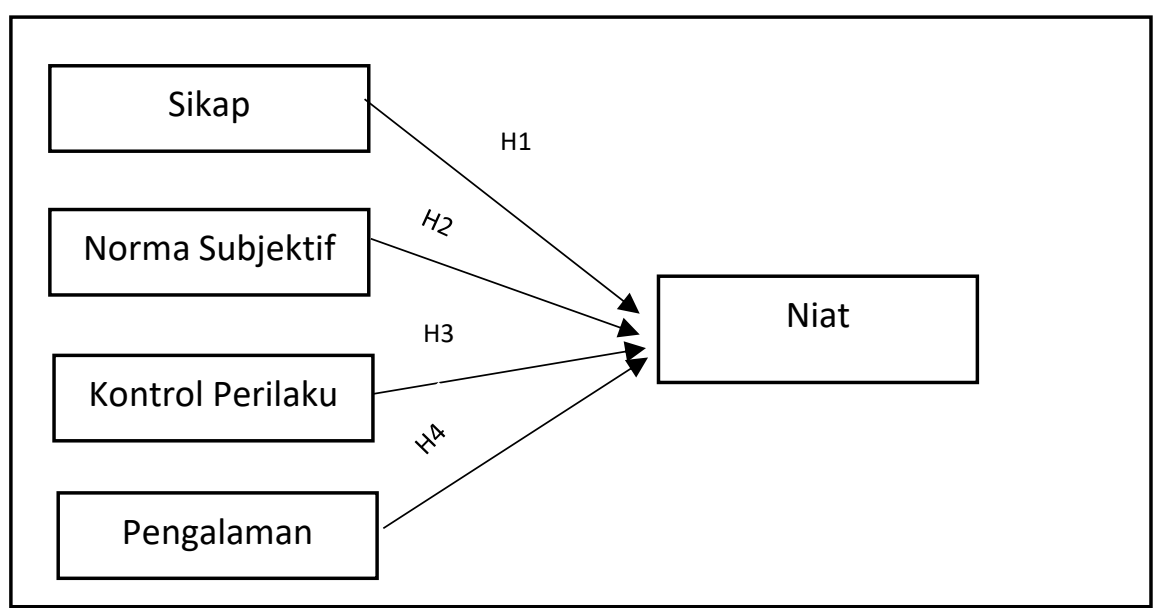

\section{Gambar 1 Model Penelitian}

\section{METODE PENELITIAN}

Penelitian ini berjenis kuantitatif dengan sumber data berupa data primer. Teknik pengambilan sampel menggunakan clustered random sampling, yakni mengambil sampel berdasarkan wilayah. Adapun sampel yang dihimpun berasal dari daerah Soloraya yang terdiri dari 6 Kabupaten dan 1 Kota yakni Sukoharjo, Karanganyar, Klaten, Sragen, Wonogiri, Boyolali dan Kota Surakarta. Jumlah sampel yang terkumpul sejumlah 96 sampel dengan menggunakan pendekatan rumus populasi wakif (responden yang pernah berwakaf, baik tunai maupun tidak) yang tidak diketahui secara pasti (Sugiyono, 2017). Data primer yang diambil menggunakan metode kuesioner secara online melalui googleform dengan penilaian skala likert.

Analisis yang digunakan menggunakan regresi linear berganda dengan pemodelan menggunakan SmartPLS. Analisis regresi adalah seperangkat metode statistik yang digunakan untuk memperkirakan hubungan antara variabel dependen dan satu atau lebih variabel independen (Ghozali, I., \& Latan, 2015). Adapun formulasi estimasi disajikan sebagai berikut:

$$
Y=\alpha+\beta_{\text {Sikap }}+\beta_{\text {Norma Subyektif }}+\beta_{\text {Kontrol Perilaku }}+\beta_{\text {Pengalaman }}+\varepsilon
$$

\section{HASIL DAN PEMBAHASAN}

\section{Demografi}

Sebelum melakukan analisis pengolahan data, dalam penelitian ini perlu disajikan gambaran tentang berbagai karakteristik responden dalam upaya melengkapi dan memperkuat penelitian. Beberapa karakteristik yang dijelaskan antara lain jenis kelamin, usia, pendidikan terakhir, pekerjaan dan asal wilayah. Gambaran umum tersebut dapat diinformasikan sebagai berikut: 
Tabel 2 : Demografi Responden

\begin{tabular}{llll}
\hline Item & $\%$ & Item & $\%$ \\
\hline Gender & & Umur & \\
\hline Laki-laki & 49 & $<18$ Year & 1,0 \\
Perempuan & 51 & $18-25$ Year & 21,9 \\
& & $25-50$ Year & 46,9 \\
& & $>50$ Year & 30,2 \\
\hline Education & & Pekerjaan & \\
\hline SD & 2 & Mahasiswa & 21,9 \\
SMP & 3 & PNS/TNI/POLRI & 9,4 \\
SMA & 43 & Swasta & 17,7 \\
S1 & 39 & IRT & 22,9 \\
S1 & 14 & Lain-lain & 28,1 \\
\hline Pendapatan (juta Rp) & & Asal & \\
\hline$<1$ & 0,0 & Sukoharjo & 15,6 \\
$1-3$ & 11,0 & Karanganyar & 17,7 \\
$3-5$ & 46,0 & Sragen & 12,5 \\
$>5$ & 39,0 & Boyolali & 15,6 \\
& & Klaten & 16,7 \\
& & Wonogiri & 14,6 \\
& & Kota Surakarta & 8,3 \\
\hline
\end{tabular}

Sumber: Data diolah

\section{Analisis Data}

Pengujian inner model digunakan untuk melihat validitas konstruk dari variable eksogen maupun endogennya. Pengujian ini dilakukan dengan melihat nilai loading factor, apabila nilai melebihi 0,5 maka model dikatakan valid (Ghozali, I., \& Latan, 2015). Berdasarkan gambar dibawah, diperoleh hasil bahwa nilai semua loading factor lebih besar dari 0,5 sehingga evaluasi atas model inner dapat dilanjutkan untuk tahap berikutnya.

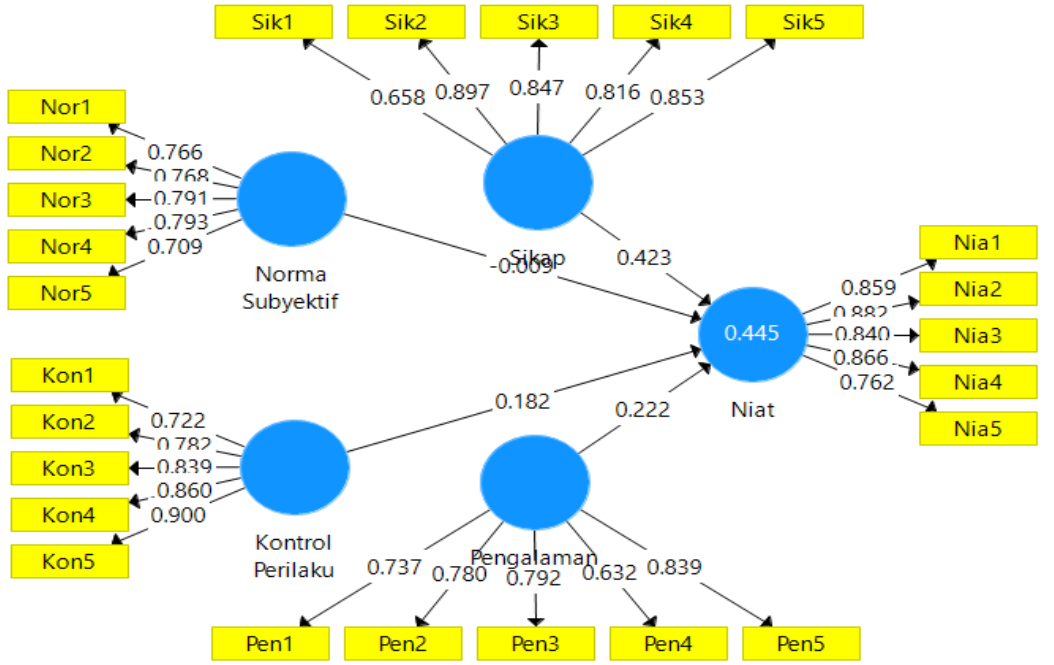

Gambar 2 Loading Factor

Pengukuran model eksternal dapat dilakukan dengan menguji validitas konvergen, validitas diskriminan dan unidimensionalitas. Selain nilai loading factor, validitas konvergen juga dapat dilihat dari average variance extracted (AVE). Berikut disajikan output AVE: 


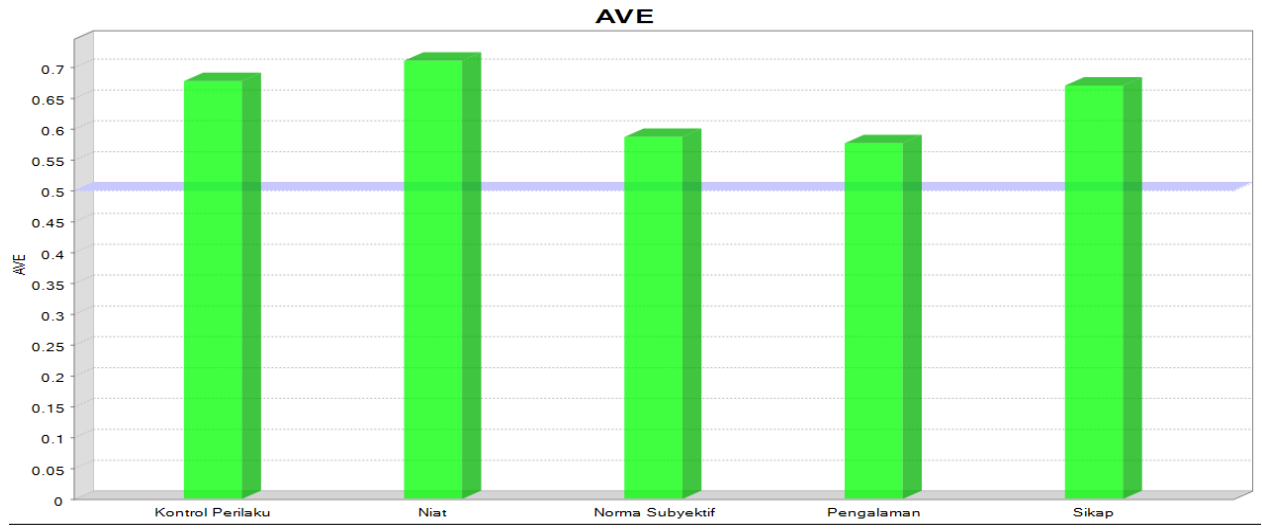

Sumber: Data diolah

\section{Gambar 3. Average Variance Extracted (AVE)}

Dalam penelitian ini nilai AVE masing-masing konstruk berada di atas 0,5. Oleh karena itu tidak ada masalah validitas konvergen dalam model yang diuji. Untuk memastikan tidak ada masalah yang terkait dengan pengukuran, langkah terakhir dalam mengevaluasi model eksternal adalah dengan menguji model Unidimensionalitas. Uji unidimensionalitas dilakukan dengan menggunakan indikator composite reliability dan cronbach alpha. Untuk kedua indikator ini titik potongnya adalah 0,7
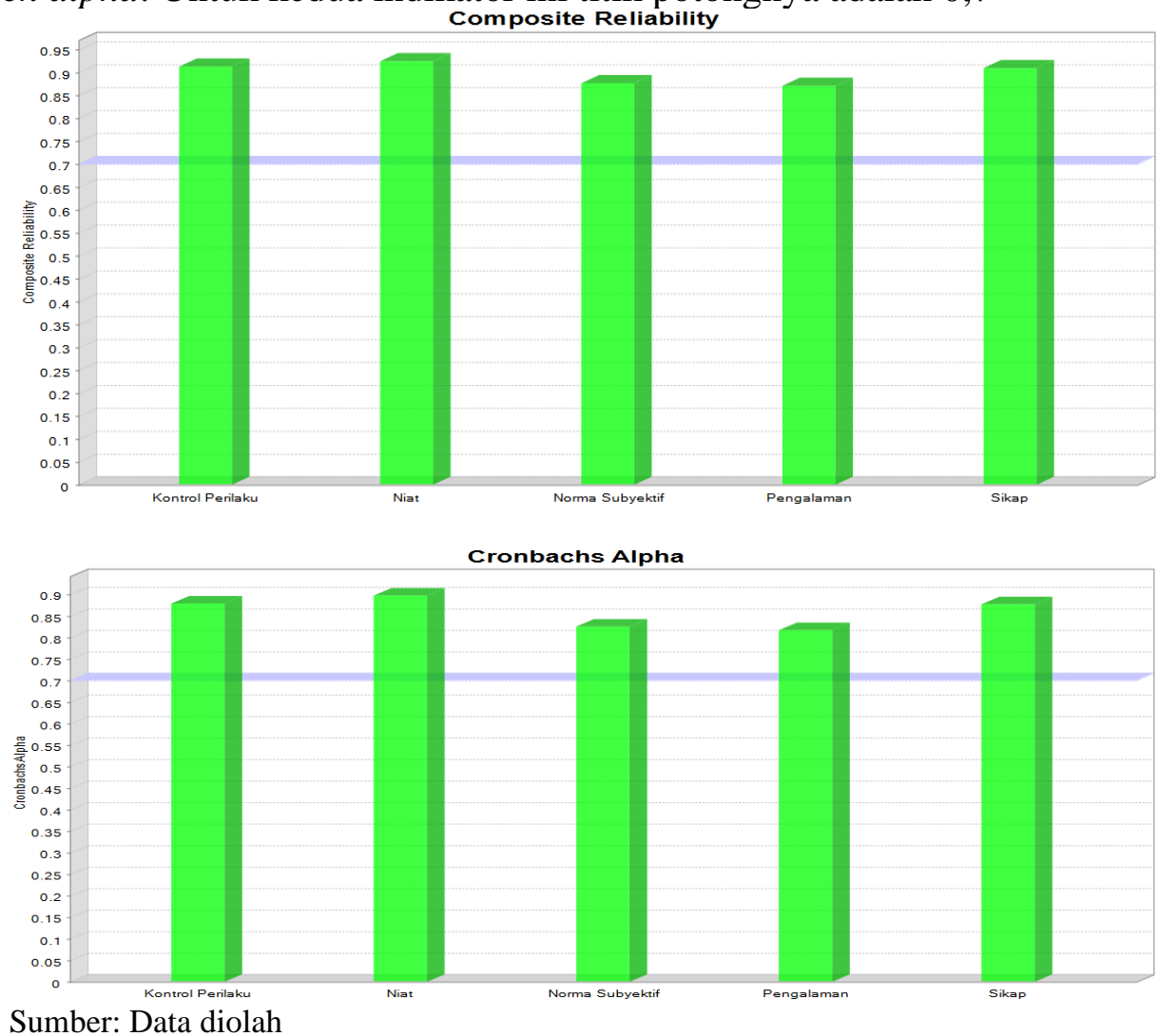

\section{Gambar 4. Unidimensinality (Pengujian Reliabilitas)}

Tabel di atas menunjukkan bahwa semua konstruk memiliki nilai composite reliability dan cronbachs alpha di atas 0,7 . Oleh karena itu, tidak ada masalah reliabilitas/ unidimensionalitas dalam model yang ditentukan.

Selanjutnya dilakukan uji parsial. Pengujian parsial atau disebut juga uji-t pada regresi linier berganda. Analisis bertujuan untuk mengetahui apakah variabel independen secara parsial (individu/masing-masing variabel) memiliki pengaruh yang signifikan 
terhadap variabel dependen. Dalam penelitian ini terdapat 4 variabel, dimana sikap, norma subyektif, kontrol perilaku dan pengalaman sebagai predictor (independen) dan niat sebagai criteria (dependen). Rangkuman hasil regresi SEM-PLS adalah sebagai berikut:

Tabel 3. Uji Parsial

\begin{tabular}{lcccc}
\hline \multicolumn{1}{c}{ Variabel } & Koefisien & t-statistik & Signifikansi & Keputusan \\
\hline Sikap & 0,182 & 1,608 & 0,048 & Ditolak \\
Norma Subyektif & $-0,009$ & 0,065 & 0,948 & Ditolak \\
Kontrol Perilaku & 0,222 & 2,198 & 0,028 & Diterima \\
Pengalaman & 0,423 & 3,015 & 0,003 & Diterima \\
\hline Adj R Square & 0,445 & & & \\
\hline
\end{tabular}

Sumber: Data diolah

Berdasarkan hasil pengujian diatas diperoleh informasi bahwa variable subyektif secara parsial tidak berpengaruh terhadap niat untuk berwakaf tunai, dengan nilai signifikansi lebih dari $0,05(0,948)$. Sementara untuk variabel sikap $(0,048)$, kontrol perilaku $(0,028)$ dan pengalaman $(0,003)$, diperoleh hasil bahwa secara parsial berpengaruh terhadap niat untuk berwakaf, dengan nilai signifikansi lebih kecil dari 0,05. Nilai koefisien determinasi sebesar 0,445 yang berarti variabel dalam teori perilaku berencana mampu mempengaruhi niat sebesar 44,5\% sementara sisanya dipengaruhi faktor diluar model.

\section{Pembahasan}

Hasil temuan dalam penelitian ini menjelaskan bahwa norma subyektif tidak berpengaruh terhadap niat seseorang untuk melakukan wakaf tunai. Hal ini disebabkan bahwa keinginan untuk berwakaf, berasal dari diri pribadi. Oleh karenanya penelitian ini menemukan fakta bahwa sikap yang merupakan representasi dari dorongan internal diri, memiliki pengaruh untuk melakukan wakaf, termasuk wakaf tunai. Responden dalam penelitian ini mengungkapkan bahwa wakaf merupakan bentuk ibadah sehingga orientasi wakif untuk berwakaf adalah efek dari religiusitas seperti yang dikemukakan Osman (2014). Agama memainkan peranan instrinsik dalam motivasi untuk mengkesekusi tindakan, dalam hal ini adalah berwakaf tunai.

Sebagian responden, memang tidak terpengaruh adanya efek dari luar individu, yakni tidak terpicu oleh role model yang dicontohkan orang lain, baik keluarga, teman ataupun idola yang telah melakukan wakaf tunai. Aspek sosial yang muncul dari orang lain hanya sebatas motivasi untuk membantu dan menolong, demi maksimalisasi ditribusi kekayaan. Bukan faktor dorongan ikut-ikutan dengan orang lain yang terlebih dahulu melakukan donasi dalam bentuk wakaf tunai, sehingga dalam konteks penelitian ini norma subyektif tidak memainkan peranan dalam menciptakan niat perilaku untuk berwakaf tunai. Hal ini sependapat dengan temuan Huda et al., (2012); I. Osman et al., (2019; Sakti et al., (2016).

Temuan lain dalam penelitian ini bahwa kontrol perilaku berpengaruh terhadap niat melakukan wakaf tunai. Kontrol perilaku yang dirasakan berdampak positif pada niat wakaf untuk berkontribusi kembali pada wakaf tunai. Ada kemungkinan bahwa hasil ini mungkin dipengaruhi oleh pengetahuan tentang wakaf dan sumber daya keuangan. Pengetahuan ini memudahkan para wakif untuk berwakaf, terlebih di era transaksi digital. Beberapa lembaga wakaf sudah berinovasi berupa integrasi dengan teknologi keuangan (fintech), dengan menghadirkan layanan wakaf dalam aplikasi baik melalui layanan atm, mobile banking, internet banking, e-wallet, marketplace dll. Terlebih dalam kondisi 
pandemi, maka tuntutan cashless menjadi kebutuhan vital dalam setiap transaksi. Selain itu, orang lebih rela berwakaf ketika memiliki tambahan pendapatan. Kombinasi dari elemen-elemen ini mempengaruhi kontrol perilaku yang dirasakan. Temuan ini serupa dengan yang dilaporkan oleh beberapa penelitian terdahulu (Heikal et al., 2014; Kashif \& de Run, 2015; Knowles et al., 2012; Linden, 2011; I. Osman et al., 2019; Smith \& McSweeney, 2007) yang mengungkapkan bahwa kontrol perilaku yang dirasakan sebagai anteseden niat untuk berdonasi (wakaf).

Pengalaman dalam penelitian ini juga memiliki pengaruh yang positif dan signifikan. Pengalaman didefinisikan sebagai sesuatu pengetahuan atau keterampilan dari melakukan, melihat, atau merasakan sesuatu. Pengalaman sendiri dalam psikologi dibedakan atas pengalaman kognitif, afektif, behavioral, sensory dan sosial. Pengalaman kognitif adalah aliran sadar yang dikendalikan oleh seseorang. Sebenarnya proses psikologis dan rangsangan seseorang berasal dari penerimaan informasi yang ditransmisikan dari rangsangan pengalaman penggunaan pribadi. Kemudian secara afektif, akan memunculkan perasaan gembira, senang dan kepuasan. Berdasarkan pengalaman yang dirasakan responden, seseorang yang telah melakukan donasi/sumbangan, dalam bentuk wakaf atau sedekah pada umumnya, akan memunculkan perasaan tenteram, nyaman dan bahagia karena telah berbuat baik seperti yang di anjurkan dalam agama. Sehingga perasaan yang muncul akibat stimulasi melakukan sesuatu (wakaf), berimbas pada keinginan untuk mengulang kembali (retention) dan menciptakan habbit (behavior experience). Tujuannya adalah untuk kemaslahatan umat (social experience). Paco \& Rodrigues, (2014) mencatat pentingnya donasi masa lalu untuk memprediksi niat donasi di masa depan. Mereka menyimpulkan bahwa sangat penting untuk memfasilitasi proses donasi untuk memuaskan donor (wakif) dan meyakinkannya untuk mengulangi perilakunya. Senada yang disampaikan Heikal et al. (2014) mengungkapkan bahwa perilaku masa lalu memiliki determinan terkuat dari niat membayar zakat komersial.

\section{PENUTUP}

Wakaf merupakan salah satu bentuk sedekah yang dianjurkan dalam Islam. Wakaf tunai dianggap sebagai metode yang praktis karena mudah dan terjangkau untuk disumbangkan dibandingkan dengan bentuk wakaf lainnya. Wakaf tunai memiliki semangat untuk penahanan sejumlah uang dari para donatur (wakif) dan didedikasian hasil penggunaannya untuk kemaslahatan dan kejahteraan umat, tanpa menghilangkan unsur pokoknya. Terlebih, di Indonesia sendiri idealnya memiliki potensi yang besar dalam pengelolaan wakaf untuk kegiatan yang produktif. Oleh karenanya, perlu dilakukan evaluasi untuk melihat respon masyarakat dalam melakukan wakaf tunai. Dengan pendekatan teori perilaku berencana (TPB Extended), ditemukan fakta dalam penelitian ini bahwa sikap yang merepresentasikan dorongan dalam diri, memiliki pengaruh yang signifikan terhadap niat seseorang dalam berwakaf tunai. Sementara pengaruh luar individu, seperti orang lain, tidak memiliki pengaruh. Hal ini disebabkan bahwa motivasi orang berwakaf adalah lebih karena ingin melaksanakan anjuran agama diluar kegiatan yang bersifat wajib. Oleh karenanya, pada penelitian selanjutnya perlu ditambahkan religiusitas untuk memoderasi hubungan terhadap niat, sehingga dapat diketahui apakah motivasi beragama memang memperkuat hubungan atau justru melemahkan. Temuan lain bahwa di era digital, dan transaksi online yang berkembang pesat dalam beberapa tahun ini, memicu orang untuk berwakaf tunai, karena fasilitas yang semakin baik. Selain itu, pengalaman juga berdampak positif terhadap niat melakukan 
wakaf tunai. Alasannya, faktor perasaan diri yang muncul memberikan stimulan untuk melakukan kembali (retensi) perilaku yang dilakukan sebelumnya, yakni berwakaf tunai.

\section{DAFTAR PUSTAKA}

Abdila, R. (2020). Mandiri Syariah Catat Pengguna Mobile Banking Meningkat 2 Persen. Tribunnews.Com.

Ahmad, M. (n.d.). Cash Waqf: Historical Evolution, Nature and Role as an Alternative to Riba-Based Financing for the Grass Root |. Retrieved June 28, 2021, from https://journals.iium.edu.my/iiibf-journal/index.php/jif/article/view/70

Ajzen, I. (1985). From Intentions to Actions: A Theory of Planned Behavior. In Action Control (pp. 11-39). Springer Berlin Heidelberg. https://doi.org/10.1007/978-3642-69746-3_2

Ajzen, I. (1991). The Theory of Planned Behavior. Organizational Behavior and Human Decision Processes, 50(2), 179-211. https://doi.org/10.1016/0749-5978(91)90020$\mathrm{T}$

Aziz, N. N. A., Aziz, N. A. A., Aziz, N. A. A., Omar, Z., \& Hassan, W. H. A. W. (2015). A Review on the Emergence and Growth of Halal Studies. Procedia Economics and Finance, 31, 325-332. https://doi.org/10.1016/s2212-5671(15)01204-6

BRIS. (2019). Public Expose 2019. In BRI Syariah.

BWI. (2019). Data Nazhir Wakaf Uang Terdaftar Di Badan Wakaf Indonesia.

BWI. (2021). Menelisik Manfaat Potensi Wakaf Uang untuk Bantu Kaum Dhuafa. 05 Februari 2021.

Eagly, A. H., \& Chaiken, S. (1993). The Psychology of Attitudes: Book Review. In Fort Worth, TX: Harcourt Brace Jovanovich.

Ghozali, I., \& Latan, H. (2015). Partial Least Squares Konsep, Teknik dan Aplikasi menggunakan Program SmartPLS 3.0 (2nd ed.). Badan Penerbit Universitas Diponegoro.

Haq, A. F. (2012). Wakaf Kontempores, Dari Teori Ke Aplikasi. Maliyah : Jurnal Hukum Bisnis Islam, 2(2). http://jurnalfsh.uinsby.ac.id/index.php/maliyah/article/view/338

Harun, F. M., Possumah, B. T., Mohd Shafiai, M. H. Bin, \& Nor, A. H. M. (2016). Issues and Economic Role of Waqf in Higher Education Institution: Malaysian Experience. Al-Iqtishad: Journal of Islamic Economics, 8(1), 149-168. https://doi.org/10.15408/aiq.v8i1.2514

Hasyim, F. (2018). The Determinant of Takaful Acceptance: Theory of Reasoned Action Approach. Journal of Finance and Islamic Banking, 1(1). https://doi.org/10.22515/jfib.v1i1.1246

Hasyim, F. (2019). Peer To Peer Lending As Alternative Online Microfinance Platform: Threat and Challenge To Islamic Microfinance. Indonesian Journal of Islamic Literature and Muslim Society, 4(2), 2528-1194. https://doi.org/10.22515/islimus.v4i2.1491

Haura, A., Baga, L. M., \& Tanjung, H. (2015). Analisis Pengelolaan Wakaf Uang pada Koperasi Jasa Keuangan Syariah (Pendekatan Analytical Network Process). Al- 
Muzara'ah, 3(2), 89-105. https://doi.org/10.29244/jam.3.2.89-105

Heikal, M., Hasballah, F., \& Khaddafi, M. (2014). The Intention to Pay Zakat Commercial: An Application of Revised Theory of Planned Behavior. Journal of Economics and Behavioral Studies. https://www.researchgate.net/publication/291522293_The_Intention_to_Pay_Zak at_Commercial_An_Application_of_Revised_Theory_of_Planned_Behavior

Hill, R. J., Fishbein, M., \& Ajzen, I. (1977). Belief, Attitude, Intention and Behavior: An Introduction to Theory and Research. Contemporary Sociology, 6(2), 244. https://doi.org/10.2307/2065853

Huda, N., Rini, N., Mardoni, Y., \& Putra, P. (2012). The Analysis of Attitudes, Subjective Norms, and Behavioral Control on Muzakki's Intention to Pay Zakah. In International Journal of Business and Social Science (Vol. 3, Issue 22). www.ijbssnet.com

Iman, A. H. M., \& Mohammad, M. T. S. H. (2017). Waqf as a framework for entrepreneurship. Humanomics, 33(4), 419-440. https://doi.org/10.1108/H-012017-0015

indotelko.com. (2020). Pemerintah permudah wakaf uang melalui kanal digital. Indotelko.Com.

Kashif, M., \& de Run, E. C. (2015). Money donations intentions among Muslim donors: An extended theory of planned behavior model. International Journal of Nonprofit and Voluntary Sector Marketing, 20(1), 84-96. https://doi.org/10.1002/nvsm.1519

Kashif, M., Sarifuddin, S., \& Hassan, A. (2015). Charity donation: intentions and behaviour. Marketing Intelligence \& Planning, 33(1), 90-102. https://doi.org/10.1108/MIP-07-2013-0110

Khalifa, M., \& Shen, K. N. (2008). Drivers for transactional B2C M-commerce adoption: Extended theory of planned behavior. Journal of Computer Information Systems, 48(3), 111-117. https://doi.org/10.1080/08874417.2008.11646027

KNKS. (2019). Menangkap Peluang Tren Wakaf Produktif. INSIGHT Komite Nasional Keuangan Syariah (KNKS).

Knowles, S. R., Hyde, M. K., \& White, K. M. (2012). Predictors of Young People's Charitable Intentions to Donate Money: An Extended Theory of Planned Behavior Perspective. Journal of Applied Social Psychology, 42(9), 2096-2110. https://doi.org/10.1111/j.1559-1816.2012.00932.x

Linden, S. Van De. (2011). Charitable Intent: A Moral or Social Construct? A Revised Theory of Planned Behavior Model. Current Psychology, 30(4), 355-374. https://doi.org/10.1007/s12144-011-9122-1

Mohamad Suhaimi, F., Ab Rahman, A., \& Marican, S. (2014). The role of share waqf in the socio-economic development of the Muslim community. Humanomics, 30(3), 227-254. https://doi.org/10.1108/H-12-2012-0025

Mohsin, M. I. A. (2013). Financing through cash-waqf: a revitalization to finance different needs. International Journal of Islamic and Middle Eastern Finance and Management, 6(4), 304-321. https://doi.org/10.1108/IMEFM-08-2013-0094 
Osman, A. F. (2014). An Analysis Of Cash Waqf Participation Among Young Intellectuals. Proceedings of International Academic Conferences. https://ideas.repec.org/p/sek/iacpro/0100111.html

Osman, I., Ma'in, M., \& Muda, R. (2019). Determinants Of Behavioural Intention Towards Green Investments: The Perspetives If Muslims. In International Journal of Islamic Business (Issue 1).

Ouellette, J. A., \& Wood, W. (1998). Habit and Intention in Everyday Life: The Multiple Processes by Which Past Behavior Predicts Future Behavior. Psychological Bulletin, 124(1), 54-74. https://doi.org/10.1037/0033-2909.124.1.54

Paco, A. Do, \& Rodrigues, R. G. (2014). Branding In NGO-ITS Influence on The Intention to Donate. \& Sociology, 7. https://doi.org/10.14254/2071

Pavlou, P. A., \& Chai, L. (2002). What Drives Electronic Commerce Across Cultures? A Cross-Cultural Empirical Investigation of The Theory of Planned Behavior. In Journal of Electronic Commerce Research (Vol. 3, Issue 4).

Philippsen, Y. (n.d.). Factors influencing students' intention to recycle.

Rouibah, K. (2009). User Acceptance of Internet Banking In Malaysia: Test of Three Competing Models. June 2014. https://doi.org/10.4018/jea.2009010101

Sakti, M. R. P., Bin Mohd Thas Thaker, H., Qoyum, A., \& Qizam, I. (2016). Determinants Of Cash Waqf Contribution In Klang Valley and Selangor: A SEM Approach. Journal of Islamic Monetary Economics and Finance, 2(1), 111-144. https://doi.org/10.21098/jimf.v2i1.593

Setiawan, S. R. D. (2018). OJK: Tahun 2018, Perbankan Siap Mendukung Pertumbuhan Ekonomi.

Shaikh, S. A., Ismail, A. G., \& Mohd Shafiai, M. H. (2017). Application of waqf for social and development finance. ISRA International Journal of Islamic Finance, 9(1), 514. https://doi.org/10.1108/IJIF-07-2017-002

Shalender, K., \& Sharma, N. (2021). Using extended theory of planned behaviour (TPB) to predict adoption intention of electric vehicles in India. Environ Dev Sustain, 23. https://doi.org/https://doi.org/10.1007/s10668-020-00602-7

Shukor, S. A., Anwar, I. F., Aziz, S. A., \& Sabri, H. (2017). Muslim Attitude Toward Participation In Cash Waqf: Antecedents And Consequences. In International Journal of Business and Society (Vol. 18).

Shulthoni, M., \& Saad, N. M. (2018). Waqf fundraising management: A conceptual comparison between traditional and modern methods inthe waqf institutions. Indonesian Journal of Islam and Muslim Societies, 8(1), 57-86. https://doi.org/10.18326/ijims.v8i1.57-86

Simamora, T. P., \& Djamaludin, M. D. (2020). Analysis of Intention to Buy Cinema ETickets Among IPB Students with Theory of Planned Behavior (TPB) Approach. Journal of Consumer Sciences, 5(1), 58-72. https://doi.org/10.29244/JCS.5.1.5872

Smith, J. R., \& McSweeney, A. (2007). Charitable giving: The effectiveness of a revised theory of planned behaviour model in predicting donating intentions and behaviour. 
Journal of Community and Applied Social Psychology, 17(5), 363-386. https://doi.org/10.1002/casp.906

Sommer, L. (2011). The Theory Of Planned Behaviour And The Impact Of Past Behaviour. International Business \& Economics Research Journal (IBER), 10(1). https://doi.org/10.19030/iber.v10i1.930

Sugiyono. (2017). Metode Penelitian Bisnis: Pendekatan Kuantitatif, Kualitatif, Kombinasi, $R \& D$ (S. Y. Suryandari (ed.); 3rd ed.). CV Alfabeta.

Syahroni, O., \& Karim, A. A. (2016). Maqasid Bisnis dan Keuangan Islam: Sintesis Fikih dan Ekonomi, Jakarta: PT. Raja Grafindo Persada.

Thaker, M. A. B. M. T., Mohammed, M. O., Duasa, J., \& Abdullah, M. A. (2016). Developing cash waqf model as an alternative source of financing for micro enterprises in Malaysia. Journal of Islamic Accounting and Business Research, 7(4), 254-267. https://doi.org/10.1108/JIABR-09-2014-0029

Wong, S. L., Hsu, C. C., \& Chen, H. S. (2018). To buy or not to buy? Consumer attitudes and purchase intentions for suboptimal food. International Journal of Environmental Research and Public Health, 15(7). https://doi.org/10.3390/ijerph15071431 